\section{Madding masses}

Hugh Freeman

Crowds, Psychology, and Politics, 1871-1899. By Jaap van Ginneken. Cambridge University Press: 1992. Pp. 269. £35, $\$ 59.95$.

MENTION the psychology of crowds to almost anyone with a passing knowledge of the subject, and the automatic response is "Le Bon". Nearly a century after its publication, his Psychology of Crowds remains a principal reference point for the study of mass psychology. But since both its text and the author's life have already been thoroughly explored, why the present book?

Van Ginneken explains that over the course of 20 years, he came to realize that the conventional history of crowd psychology was substantially wrong biased particularly by undue emphasis on French contributions, on those of a few well-known figures, and on a monorather than multidisciplinary perspective. He therefore set out to reconstruct how the early modern theories of crowd behaviour evolved, and to interpret their meaning in a culturally relative sense. He has retraced this intellectual tradition back to the work of Taine - seen as its real founder - and rediscovered a missing link (Fournial) with the better known Sighele, Le Bon and Tarde. Each of these basic theorists is examined in terms of his life and his work's social context, intellectual background and influence on science and public attitudes. This is an ambitious project, and one that is broadly successful.

Taine was a polymath; starting as a literary scholar, he became a professor of art history, and then founded scientific psychology in France, almost certainly influencing Freud. On the basis of Darwinism, he saw the excesses of crowds as a retreat from civilization, a view that he formalized in his theory of "dissolution"; experience of the Paris Commune then made him focus on mob rule, which figured prominently in his massive Origins of Contemporary France. Van Ginneken acknowledges this pioneering application of social and psychological mechanisms to the study of political processes, but finds Taine uninterested in the reasons why crowds behaved as they did. His political conservatism, further alarmed by the technical and media developments of the belle époque, was taken over by Le Bon, who failed to acknowledge this debt, among others.

Because almost all the work on crowd psychology of this period was in France or Italy, it has usually been described as the 'Latin School', but van Ginneken

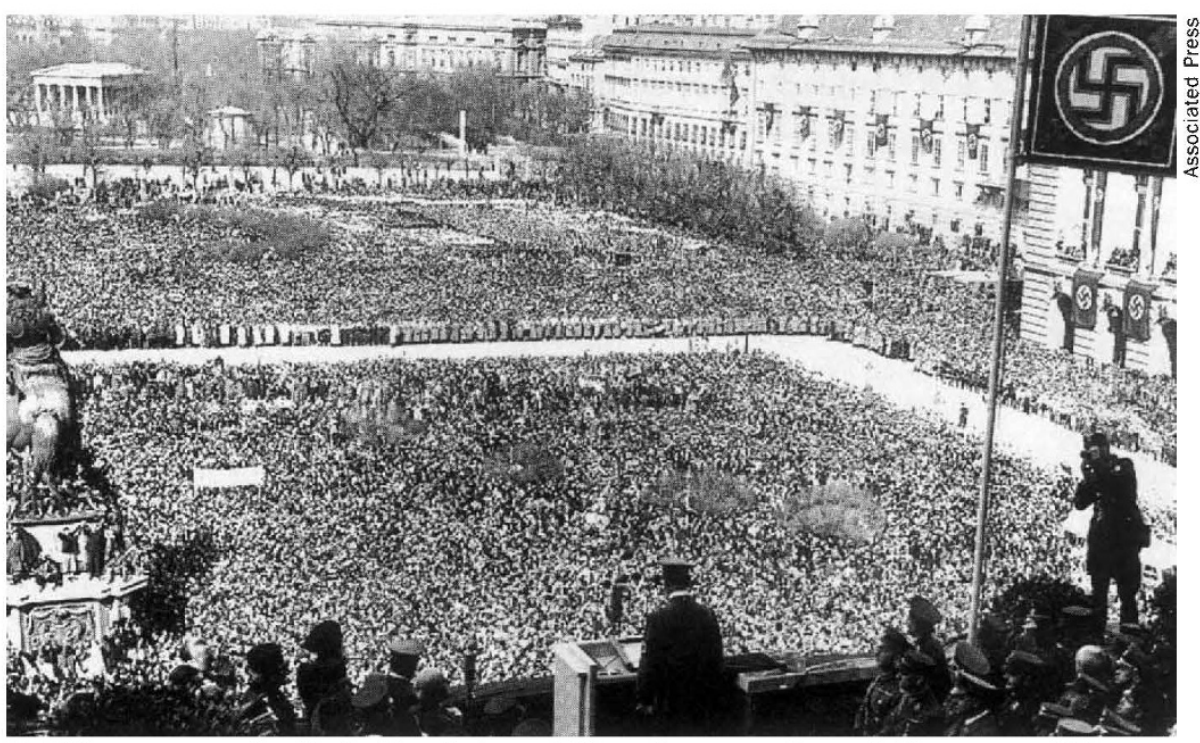

Rabble rouser - Le Bon's Psychology of Crowds was a strong influence on Hitler.

shows that, unlike the French, the Italian writers were essentially criminologists who intervened in the legal consequences of crowd disorders and were politically radical. Sighele saw crowds as developing a kind of mental unity, particularly when they were very large; like others, he moved increasingly to a nationalist position, providing one contribution to the intellectual rag-bag that later made up fascism. Here, the two national trends converged, since Le Bon was also a strong influence on Mussolini, who skilfully manipulated crowd violence to intimidate opponents, as he was on Hitler.

In both Latin countries, physical anthropology was then believed to provide the key to many cultural and social phenomena, including deviant behaviour. (The uniqueness of fingerprints, incidentally, was first reported by an English medical missionary from Tokyo, in a letter to Nature). Fournial, a French colonial doctor, is identified by van Ginneken as the missing link in the transition from this scientific blind alley to a more psychological analysis. His chosen mechanism was "social imitation", which shared qualities with hypnosis, and this contribution also was used but unmentioned by Le Bon.

In France, hypnotic suggestion was then a scientific battleground between Charcot's school in Paris, who saw it as necessarily linked to hysteria, and those with a wider view in Nancy; Le Bon used this work freely in interpreting the minds of crowds. Simultaneously with his Psychology of Crowds, Breuer and Freud in Vienna were producing Studies in Hysteria, which incorporated the same notion of successive levels of consciousness and was influenced by the same debate. The other psychological leg of Le Bon's theoretical structure was in the evolution-dissolution tradition that de- rived from Darwin and Spencer. The product was pessimistic, authoritarian, élitist and racist, even for its day. Its political background was the abortive Boulanger coup (showing crowds at their most gullible), the first mass socialist demonstrations, and spectacular acts of anarchist terrorism. Through his analysis of behaviour in the mass, Le Bon became advisor to the political élite.

The final theorist, Tarde, appears here largely as a postscript to Le Bon, but he had some importance as founder of the modern study of opinion formation. What emerges clearly from this analysis is that today's reductionism would be very misleading here. As a science, late nineteenth-century psychology was still largely unformed, and the work of its pioneers spread across what are now quite separate disciplines; this may well be what subsequently prevented the study of crowds from becoming a major focus of scientific work.

In all these fields, van Ginneken shows an easy mastery both of the literature and of previously unexploited primary sources. Although he is fluent in English, it is clearly not his native tongue, and the book failed to receive the skilful editing it needed to make sure that the quality of writing equalled that of the underlying scholarship. $\mathrm{Re}$ grettably, the text is sprinkled with sloppy phrasing, incorrect words and egregious exclamation marks; we are helpfully told that Hitler was "the German Führer" and are recommended to "see review by McGuire", only to find in the references that it is unpublished. Yet in spite of it all, van Ginneken has made a significant contribution to the intellectual history of crowd psychology.

Hugh Freeman is editor of the British Journal of Psychiatry, 21 Montagu Square, London W1H 1RE, UK. 